\title{
The number of spermatozoa, the number of ovulations per ewe, and immunization against androstenedione affect fertility and prolificacy of sheep
}

\author{
A. W. N. Cameron*†§, C. M. Oldham*, I. J. Fairnie $\downarrow$, E. J. Keogh† and \\ D. R. Lindsay* \\ Departments of ${ }^{*}$ Animal Science and $\dagger$ Clinical Biochemistry, University of Western Australia, \\ Nedlands, Western Australia 6009, Australia; and $\ddagger$ Muresk College, Northam, \\ Western Australia 6401, Australia
}

\begin{abstract}
Summary. Ewes that were untreated, fed lupins or fed lupins and immunized against androstenedione were artificially inseminated. The percentage of ewes pregnant at 36-45 days after insemination (fertility) was $8 \%$ higher in ewes that had more than one ovulation than in those that had only one ovulation. Maximum fertility was achieved with $50 \times 10^{6}$ spermatozoa and this did not vary with the number of ovulations that ewes had. Among the pregnant, twin-ovulating ewes, embryo survival increased as the number of spermatozoa inseminated increased from $25 \times 10^{6}$ to $400 \times 10^{6}$. Immunization of ewes against androstenedione increased ovulation rate but reduced fertility, and reduced embryo survival among twin-ovulating ewes.
\end{abstract}

Keywords: artificial insemination; ovulation rate; fertility; androstenedione; embryo survival; sheep

\section{Introduction}

A survey of Western Australian Merino flocks revealed that the proportion of ewes pregnant (fertility) was low, with only $72 \%$ of ewes lambing after a mating period that lasted for several oestrous cycles, even though $97 \%$ were marked by rams (Knight et al., 1975). In a comparable survey of New Zealand flocks $96 \%$ of ewes lambed (Kelly, 1982). Among the Western Australian flocks each $10 \%$ increase in the mean ovulation rate of a flock was associated with a $3.8 \%$ increase in fertility (Lindsay et al., 1975). This relationship between fertility and ovulation rate may partly explain the relatively low fertility of Western Australian flocks, since the mean ovulation rate was 1.15 in these (Knight et al., 1975) compared to 1.61 in the New Zealand ewes (Kelly, 1982).

One reason why increased ovulation rate leads to more ewes lambing is because conception rates are higher in ewes with more than 1 ovulation: Kelly \& Johnstone (1983) reported 6.7\% more ewes with 2 ovulations than those with 1 ovulation remained pregnant after natural mating, but Moore (1981) found the difference in fertilization rates between ewes with 1 or more than 1 ovulation was several times larger than this. Sperm transport may be more efficient in ewes having 2 rather than 1 ovulations. Evidence in support of this hypothesis includes the reports of increased peak plasma concentrations of oestradiol-17 $\beta$ in association with increased follicular development after the administration of PMSG (Evans \& Robinson, 1980), improved sperm transport in ewes treated with oestrogen at the time of mating (Hawk \& Cooper, 1975; Hawk et al., 1978) and the efficiency of sperm transport in ovariectomized ewes increasing with the dose of oestrogen used to

\$Present address: Centre for Early Human Development, Monash Medical Centre, Monash University, Clayton, Victoria 3168, Australia. 
induce oestrus (Allison \& Robinson, 1972; Croker et al., 1975). Furthermore, sperm transport in ewes inseminated at their first oestrus after treatment with progesterone-impregnated sponges generally increased with the dose of PMSG administered at the time of sponge withdrawal (Pearce, 1981).

There is evidence that, among twin-ovulating ewes that do conceive, the number bearing only one lamb is influenced by rams. Variations in semen quality (Hulet et al., 1965; Dun \& Hamelton, 1965), ram:ewe ratio (Fowler, 1982) and genotype of the ram (Burfening et al., 1977) have all been associated with variation in the number of lambs born per ewe lambing (prolificacy).

The following experiments were designed to assess the relationships between the number of spermatozoa inseminated and the number of ovulations per ewe, and fertility and prolificacy of ewes.

\section{Materials and Methods}

Animals. Merino ewes, aged 2.5-3.5 years, were used at Muresk Agricultural College, $100 \mathrm{~km}$ east of Perth, Western Australia. The 1018 ewes were inseminated in the second half of February when the daily maximum shade temperature was regularly $>40^{\circ} \mathrm{C}$. Throughout the experiment the ewes grazed wheat stubbles. For ease of management oestrus was synchronized by using sponges containing $60 \mathrm{mg}$ medroxyprogesterone acetate (MAP; Repromap, Upjohn, Melbourne, Australia) with 300 i.u. PMSG (Pregnecol: Heriot Agvet, Melbourne) administered at the time of sponge withdrawal. Ewes were inseminated at the second oestrus after the sponges were withdrawn.

Manipulation of ovulation rate. The ewes were divided into 3 flocks, designated C (control), L (lupin) and FL (Fecundin-lupin). Ewes in Flock $\mathrm{C}$ were untreated and run in a separate paddock until they were detected in oestrus. Those in Flocks L and FL were treated to increase ovulation rate. Ewes in Flock L were fed $750 \mathrm{~g}$ per head per day of lupin grain, starting 8 days before the first expected date of oestrus (Oldham \& Lindsay, 1984). Ewes in Flock FL received the same regimen of lupin supplementation and in addition were immunized against androstenedione by administering $2 \mathrm{ml}$ Fecundin (Glaxo Australia, Boronia, Victoria) 6-7 weeks, and then 3-4 weeks, before insemination began.

Artificial insemination. Oestrus was detected by using wethers that were treated with testosterone (Banrot: Wellcome Australia Ltd; Croker et al., 1982) and fitted with Sire-sine harnesses. The oestrous ewes were removed shortly after dawn each morning. The oestrous ewes from all 3 groups were mixed together and inseminated in a random order as soon as possible.

Semen was collected from 1.5-year-old Merino rams by using an artificial vagina. At any one insemination time ejaculates from 3 of the 10 rams were pooled to minimize any effects of variation in semen quality. Wave motion of the semen was measured on a scale of $0-5$ (Salamon, 1976). Only semen displaying wave motion of 4 or 5 was used. The concentration of spermatozoa was assessed by colorimetry. The semen was then diluted to a concentration of $1 \times 10^{9}$ spermatozoa/ml using ultra-high temperature-treated milk (Camperdown Dairy, Victoria) as the diluent. Cervical insemination of the ewes was then carried out, with ewes within each flock receiving $25,50,100,200$ or $400 \times 10^{6}$ spermatozoa. Ewes from all treatments were run together after insemination.

Ovulation rate. The number of ovulations was determined for each ewe by counting the corpora lutea (CL) on their ovaries at laparoscopy (Oldham et al., 1976) 5 days after insemination. Laparoscopy was not expected to affect fertility (Kelly \& Allison, 1976).

Pregnancy diagnosis. At 2 weeks after insemination the ewes were mated with entire rams fitted with Sire-sine harnesses and those returning to oestrus were assumed to be non-pregnant. The remaining ewes were examined, 36-45 days after being inseminated, by realtime ultrasound scanning (Wilkins \& Fowler, 1984) to determine the number of fetuses. Ewes diagnosed as pregnant, but in which fewer embryos than CL were counted, were re-examined 8 days later to confirm the initial diagnosis.

Statistical analyses. Data relating to the proportion of ewes pregnant were analysed by fitting a generalized linear model with a logistic link function and binomial errors (McCullagh \& Nelder, 1983) using the computer program, Genstat Mark 4.03, (Lawes Agricultural Trust, Rothamstead Experimental Station, U.K.). The initial model contained terms describing the effects of the different flocks, doses and ovulation rate, and all first order interactions. The effect of ovulation rate was examined by comparing ewes with 1 ovulation with those having more than 1 . Terms were progressively deleted from the model and changes in the deviance of the model were observed. The model finally selected contained all the significant terms, and was used to predict fertility. Data relating to the proportion of twinovulating, pregnant ewes that had 2 fetuses were analysed using the same modelling procedures. The initial model contained terms for the effects of each of the 3 flocks of ewes, for the linear and quadratic effects of the logarithm of the number of spermatozoa inseminated, and the interactions between these terms. 


\section{Results}

The proportion of ewes with more than $1 \mathrm{CL}$ was increased in Flocks $\mathrm{L}$ and FL (Table 1).

The pregnancy rate (Table 2) was generally greater in ewes with more than 1 CL compared to ewes with $1 \mathrm{CL}$, and lower in ewes in Flock FL than in those in Flocks C and L. Nevertheless, there was no evidence that the number of spermatozoa necessary to achieve maximum pregnancy rates was greater in ewes having $1 \mathrm{CL}$, rather than two or more $\mathrm{CL}$, or for ewes in the Flock $\mathrm{FL}$, rather than those in Flocks $\mathrm{C}$ and $\mathrm{L}$.

Table 1. Percentages of ewes with 1,2, 3, 4 or 5 corpora lutea (CL) and mean number of CL per ewe for the 3 flocks of ewes

\begin{tabular}{|c|c|c|c|c|c|c|c|}
\hline \multirow[b]{2}{*}{ Flock } & \multicolumn{5}{|c|}{ No. of CL } & \multirow{2}{*}{$\begin{array}{c}\text { Total no. } \\
\text { of ewes }\end{array}$} & \multirow{2}{*}{$\begin{array}{c}\text { Mean no } \\
\text { of CL } \\
\text { per ewe }\end{array}$} \\
\hline & 1 & 2 & 3 & 4 & 5 & & \\
\hline $\mathrm{C}$ & 89.6 & 10 & 0.4 & 0 & 0 & 270 & $1 \cdot 11$ \\
\hline $\mathbf{L}$ & $63 \cdot 3$ & $33 \cdot 1$ & $2 \cdot 7$ & 0.4 & 0.4 & 251 & 1.41 \\
\hline FL & $37 \cdot 1$ & $53 \cdot 5$ & $8 \cdot 7$ & $0 \cdot 6$ & 0 & 310 & $1 \cdot 73$ \\
\hline
\end{tabular}

A G-test indicated that the proportion of ewes with more than one ovulation differed significantly among the 3 flocks $(P<0.001)$.

Table 2. The effect of the number of spermatozoa inseminated and number of ovulations on the percentage of ewes (no. in parentheses) pregnant

\begin{tabular}{|c|c|c|c|c|c|c|c|c|c|c|}
\hline \multirow[b]{3}{*}{ Flock } & \multicolumn{5}{|c|}{1 ovulation } & \multicolumn{5}{|c|}{$>1$ ovulation } \\
\hline & \multicolumn{5}{|c|}{ No. of spermatozoa $\left(\times 10^{-6}\right)$} & \multicolumn{5}{|c|}{ No. of spermatozoa $\left(\times 10^{-6}\right)$} \\
\hline & 25 & 50 & 100 & 200 & 400 & 25 & 50 & 100 & 200 & 400 \\
\hline $\mathrm{C}$ (control) & $\begin{array}{c}38 \\
(48)\end{array}$ & $\begin{array}{c}45 \\
(51)\end{array}$ & $\begin{array}{c}44 \\
(48)\end{array}$ & $\begin{array}{c}33 \\
(40)\end{array}$ & $\begin{array}{c}38 \\
(48)\end{array}$ & $\begin{array}{l}40 \\
(5)\end{array}$ & $\begin{array}{l}67 \\
(6)\end{array}$ & $\begin{array}{l}67 \\
(3)\end{array}$ & $\begin{array}{c}60 \\
(10)\end{array}$ & $\begin{array}{c}100 \\
\text { (3) }\end{array}$ \\
\hline L (lupins) & $\begin{array}{c}19 \\
(32)\end{array}$ & $\begin{array}{c}48 \\
(25)\end{array}$ & $\begin{array}{c}52 \\
(27)\end{array}$ & $\begin{array}{c}52 \\
(29)\end{array}$ & $\begin{array}{c}53 \\
(40)\end{array}$ & $\begin{array}{c}39 \\
(18)\end{array}$ & $\begin{array}{c}71 \\
(24)\end{array}$ & $\begin{array}{c}44 \\
(16)\end{array}$ & $\begin{array}{c}50 \\
(20)\end{array}$ & $\begin{array}{c}50 \\
(12)\end{array}$ \\
\hline FL (fecundin-lupins) & $\begin{array}{c}33 \\
(24)\end{array}$ & $\begin{array}{c}33 \\
(27)\end{array}$ & $\begin{array}{c}30 \\
(20)\end{array}$ & $\begin{array}{c}44 \\
(25)\end{array}$ & $\begin{array}{c}30 \\
(20)\end{array}$ & $\begin{array}{c}32 \\
(38)\end{array}$ & $\begin{array}{c}54 \\
(39)\end{array}$ & $\begin{array}{c}49 \\
(37)\end{array}$ & $\begin{array}{c}36 \\
(39)\end{array}$ & $\begin{array}{c}50 \\
(40)\end{array}$ \\
\hline
\end{tabular}

The analysis of deviance (Table 3 ) revealed that the pregnancy rate was affected by the number of spermatozoa inseminated $(P<0.025)$, and the number of CL $(P<0.025)$, but the interactions between these factors were not significant. The variation between the 3 flocks was not quite significant $(P<0 \cdot 1)$. If, however, the results from the ewes in Flocks $\mathrm{C}$ and $\mathrm{F}$ were pooled, then pregnancy rates were significantly higher than for Flock FL ewes $(P<0.025)$. The values fitted by the model that contained terms for the number of spermatozoa inseminated and the number of CL (Table 4) indicate that maximum fertility was achieved with as few as $50 \times 10^{6}$ spermatozoa and was about $8 \%$ higher in ewes with more than $1 \mathrm{CL}$ than in ewes with $1 \mathrm{CL}$.

Among pregnant ewes with $2 \mathrm{CL}$, the proportion having 2 embryos rather than 1 embryo was increased when the number of spermatozoa inseminated was increased and was lowest in ewes from Flock FL (Table 5). The analysis of deviance (Table 6) revealed that terms describing the effects of the logarithm of the number of spermatozoa inseminated and of the different flocks were 
Table 3. Analysis of deviance from the model describing the proportion of ewes that were pregnant

\begin{tabular}{|c|c|c|c|}
\hline Source of variation & $\begin{array}{c}\text { Change in } \\
\text { df }\end{array}$ & $\begin{array}{c}\text { Change in } \\
\text { deviance }\end{array}$ & $\begin{array}{l}\text { Statistical } \\
\text { significance }\end{array}$ \\
\hline $\begin{array}{l}\text { Ovulation rate } \times \text { no. of } \\
\text { spermatozoa inseminated }\end{array}$ & 4 & 3.59 & NS \\
\hline $\begin{array}{l}\text { Ewe group } \times \text { no. of spermatozoa } \\
\text { inseminated }\end{array}$ & 8 & $5 \cdot 33$ & NS \\
\hline Ewe group $\times$ ovulation rate & 2 & $2 \cdot 00$ & NS \\
\hline Ewe group & 2 & 5.39 & $P<0 \cdot 1$ \\
\hline Ovulation rate & 1 & $5 \cdot 2$ & $P<0.025$ \\
\hline $\begin{array}{l}\text { No. of spermatozoa } \\
\text { inseminated }\end{array}$ & 4 & $12 \cdot 24$ & $P<0.025$ \\
\hline
\end{tabular}

Table 4. Values fitted by the model describing the effects of number of ovulations and number of spermatozoa inseminated on the percentage of pregnant ewes

\begin{tabular}{lccccc}
\hline \multirow{2}{*}{$\begin{array}{l}\text { Ovulation } \\
\text { rate }\end{array}$} & \multicolumn{5}{c}{ No. of spermatozoa inseminated $\left(\times 10^{-6}\right)$} \\
\cline { 2 - 6 } & 25 & 50 & 100 & 200 & 400 \\
\hline 1 & 29.4 & 46.6 & 41.9 & 38.9 & 42.6 \\
$>1$ & 36.8 & 54.9 & 50.2 & $47 \cdot 1$ & 50.9 \\
\hline
\end{tabular}

Table 5. The effect of the number of spermatozoa inseminated on the percentage of pregnant twin-ovulating ewes (no. in parentheses) that had 2 rather than 1 fetuses

\begin{tabular}{lccccc}
\hline & \multicolumn{5}{c}{ No. of spermatozoa inseminated $\left(\times 10^{-6}\right)$} \\
\cline { 2 - 6 } Flock & 25 & 50 & 100 & 200 & 400 \\
\hline C (control) & 100 & 75 & 100 & 83 & 67 \\
& $(2)$ & $(4)$ & $(1)$ & $(6)$ & $(3)$ \\
L (lupins) & 33 & 50 & 83 & 100 & 80 \\
& $(6)$ & $(14)$ & $(6)$ & $(7)$ & $(5)$ \\
FL (fecundin-lupins) & 22 & 53 & 40 & 54 & 69 \\
& $(9)$ & $(15)$ & $(15)$ & $(13)$ & $(16)$ \\
\hline
\end{tabular}

Table 6. An analysis of deviance from the model describing the proportion of pregnant twin-ovulating ewes that had 2 rather than 1 fetuses

\begin{tabular}{lccc}
\hline Source of variation & $\begin{array}{c}\text { Change in } \\
\mathrm{df}\end{array}$ & $\begin{array}{c}\text { Change in } \\
\text { deviance }\end{array}$ & $\begin{array}{c}\text { Statistical } \\
\text { significance }\end{array}$ \\
\hline $\begin{array}{l}\text { Ewe group } \times \text { Ln no. } \\
\text { of spermatozoa }\end{array}$ & 2 & 4.23 & NS \\
$\begin{array}{l}\text { Ln no. of spermatozoa } \\
\quad \text { Quadratic }\end{array}$ & 1 & 0.35 & NS \\
$\quad$ Linear & 1 & 7.93 & $P<0.01$ \\
Flock & 2 & 7.80 & $P<0.05$ \\
\hline
\end{tabular}


significant. There were no significant interactions and neither was the quadratic effect of number of spermatozoa inseminated significant. The values fitted by the model that contained terms for the number of spermatozoa inseminated and for the 3 flocks are shown in Fig. 1.

\section{Discussion}

In these analyses the pregnancy rate was only $8 \%$ higher in ewes that had more than $1 \mathrm{CL}$ rather than 1 CL. This is similar to the results obtained by Kelly \& Johnstone (1983) with naturally mated ewes. On the basis of the results of Lindsay et al. (1975), a 100\% increase in ovulation rate, such as occurs when all the ewes have 2 rather than $1 \mathrm{CL}$, would be associated with a $38 \%$ increase in the proportion of ewes lambing. Therefore, the relatively small difference in conception rate between ewes that had 1 or more than $1 \mathrm{CL}$ in our experiment is insufficient to explain the relationship between the mean ovulation rate and fertility of flocks reported by Lindsay et al. (1975).

The number of spermatozoa necessary to achieve maximum fertility in this experiment was not affected by the number of CL the ewes had, perhaps indicating that the efficiency of sperm transport is not affected by the number of ovulations that ewes have. There is, however, evidence that more efficient sperm transport does not necessarily result in fewer spermatozoa being required for maximum fertility. For example in ewes at their first oestrus after treatment with progestagens, in which the efficiency of sperm transport is reduced compared to ewes at natural oestrus, fertilization rates (Quinlivan \& Robinson, 1967) and lambing rates (Robinson et al., 1970) were reduced compared to naturally cyclic ewes, but these differences were constant over a range in the number of spermatozoa inseminated.

Although immunization of ewes against androstenedione led to an increase in ovulation rate, fertility in this study was reduced. The reduced fertility was not consistent with the observation of Geldard (1984) that conception rates were not affected by Fecundin provided the interval between the last injection of Fecundin and mating was greater than 2 weeks. It is, however, consistent with the reduction in egg recovery rates and in fertilization rates, the increased proportion of abnormal embryos, and the retarded embryonic growth observed in ewes treated with Fecundin (Boland $e t$ al., 1984; Nancarrow et al., 1985). In spite of the reduced fertility of ewes treated with Fecundin, their fertility plateaued when $50 \times 10^{6}$ spermatozoa were inseminated, as did fertility of the untreated ewes.

Increasing the number of spermatozoa inseminated increased the proportion of twin-ovulating pregnant ewes that had 2 embryos, confirming previous reports that rams can directly affect prolificacy (Hulet et al., 1965; Dun \& Hamelton, 1965; Burfening et al., 1977; Fowler, 1982). The mechanism by which rams affect prolificacy remains unclear. One possibility is that rams affect the proportion of twin-ovulating ewes in which only 1 of the 2 ova are fertilized, although the current understanding is that fertilization tends to occur on an all or none basis in ewes that shed 2 eggs (Restall et al., 1976; I. D. Killeen, unpublished data, cited by Kelly et al., 1978). Further research is required to establish whether the incidence of fertilization of only 1 of 2 ova in twin-ovulating ewes becomes much greater if the number of spermatozoa inseminated is reduced to levels that limit fertility.

It has been clearly established that the survival of each of the 2 embryos in ewes that shed 2 eggs can occur independently of the other (Restall et al., 1976). Rams may, therefore, affect prolificacy by affecting the rate of embryonic death. Direct evidence for this includes observations that embryonic mortality occurs more frequently if rams have the scrotum heated (Braden \& Mattner, 1970) and can differ in frequency between flocks mated with different rams (Blockey et al., 1975). Mattner \& Braden (1967) found that, the more often ewes were mated, the more spermatozoa were present in their reproductive tracts and on the zonae of their eggs and the higher was their fertility. Their data indicate that the increased fertility resulted from increased rates both of fertilization and embryonic survival. Nevertheless, there is no simple explanation as to why the number of spermatozoa inseminated should affect embryonic survival. Possibly, with low 


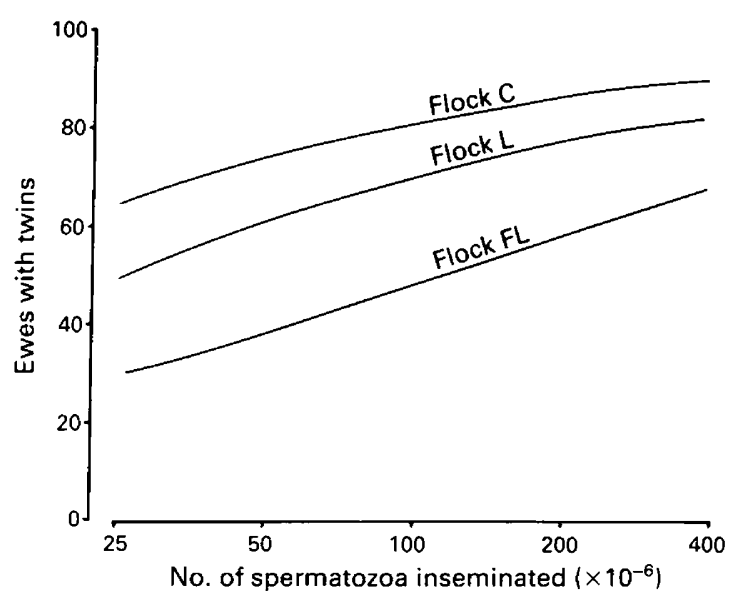

Fig. 1. Values predicted by the model describing the effect of ewe flock (C, L and FL) and number of spermatozoa inseminated on the proportion of pregnant twin-ovulating ewes that have 2 rather than 1 fetuses.

numbers of spermatozoa inseminated, too few spermatozoa reach the oviducts, leading to delayed fertilization. The fertilizable life of sheep eggs is about $12-18 \mathrm{~h}$, with delayed fertilization leading to abnormal development (Killeen \& Moore, 1970). Delayed insemination of pigs concomitantly led to reduced fertilization rates and to an increased proportion of fertilized eggs that develop abnormally (Hunter, 1967). On the other hand, there is no evidence that delayed fertilization occurs when suboptimal numbers of spermatozoa are inseminated.

Treating ewes with Fecundin reduced the percentage of pregnant, twin-ovulating ewes that had 2 embryos, relative to those in the control or lupin-fed flocks. The discrepancy between the number of CL and the number of fetuses in ewes is larger in ewes treated with Fecundin than in untreated ewes (Croker et al., 1984; Cummins et al., 1984). Since it has been reported that fewer eggs enter the oviducts and that an increased proportion of embryos develop abnormally in ewes treated with Fecundin (Nancarrow et al., 1985) this result was not surprising.

In conclusion, we have shown that an increase in ovulation rate from 1 to 2 results in only a small increase $(8 \%)$ in fertility, even though it has previously been reported to be associated with increases in fertility several times greater. Furthermore, we have demonstrated that the number of spermatozoa required to maximize fertility does not vary with ovulation rate. Finally, we have demonstrated that the number of spermatozoa inseminated can affect prolificacy.

We thank Mr Glen De'ath for statistical advice and the Wool Research Trust Fund for providing financial support.

\section{References}

Allison, A.J. \& Robinson, T.J. (1972) The recovery of spermatozoa from the reproductive tract of the spayed ewe treated with progesterone and oestrogen. J. Reprod. Fert. 31, 215-224.

Blockey, M.A. de B., Parr, R.A. \& Restall, B.J. (1975) Wastage of ova in young Merino ewes. Aust. Vet. J. 51, 298-302.
Boland, M.P., Murray, J.D., Scaramuzzi, R.J., Sutton, R., Hoskinson, I.G. \& Nancarrow, C.D. (1984) Reproductive wastage and chromosomal abnormalities in early embryos from androstenedione-immune and control Merino ewes. In Reproduction in Sheep, pp. 137-139. Eds D. R. Lindsay \& D. T. Pearce. Australian Academy of Science, Canberra. 
Braden, A.W.H. \& Mattner, P.E. (1970) The effects of scrotal heating on the semen characteristics, fecundity, and embryonic wastage. Aust. J. agric. Res 21, 509-518.

Burfening, P.J., Friedrick, R.L. \& Van Horn, J.L. (1977) Estimates of early embryonic loss in ewes mated to rams selected for high and low prolificacy. Theriogenology 7, 285-291.

Croker, K.P., Robinson, T.J. \& Shelton, J.N. (1975) The passage of spermatozoa through the cervix of ovariectomized ewes treated with progesterone and oestrogen. J. Reprod. Fert. 43, 405-410.

Croker, K.P., Butler, L.G., Johns, M.A. \& McColm, S.C. (1982) Induction of ovulation and cyclic activity in anoestrous ewes with testosterone treated wethers and ewes. Theriogenology 17, 349-354.

Croker, K.P., Cox, R.I., Johnson, T.J. \& Salerian, M. (1984) Influence of the time of injection of Fecundin ${ }^{R}$ on the reproductive performance of Merino ewes in Western Australia. In Reproduction in Sheep, pp. 329-331. Eds D. R. Lindsay \& D T. Pearce. Australian Academy of Science, Canberra.

Cummins, L.J., Spiker, S.A., Cook, C. \& Cox, R.I. (1984) The effects of steroid immunization of ewes and their nutrition on the ovulation rate and associated reproductive wastage. In Reproduction in Sheep, pp. 326-328. Eds D. R. Lindsay \& D. T. Pearce. Australian Academy of Science, Canberra.

Dun, R.B. \& Hamelton, B.A. (1965) Skin folds and Merino breeding. 2. The relative influence of the ram and the ewe on fertility and perinatal lamb mortality in flocks selected for and against skin fold. Aust. $J$. exp. Agric. Anim. Husb. 5, 805-826.

Evans, G. \& Robinson, T.J. (1980) The control of fertility in sheep: endocrine and ovarian responses to progestagen-PMSG treatment in the breeding sheep and in anoestrus. $J$. agric. Sci., Camb. 94, 69-88.

Fowler, D.G. (1982) Mating activity and reproductive performance in Merino flocks where ram percentages are $1 \cdot 0,0 \cdot 5$ and $0 \cdot 25$. Aust. J. exp. Agric. Anim. Husb. 22, 268-273.

Geldard, H. (1984) Field evaluation of Fecundin an immunogen against androstenedione. Proc. Aust. Soc. Anim. Prod. 15, 185-191.

Hawk, H.W. \& Cooper, B.S. (1975) Improvement of sperm transport by the administration of estradiol to estrous ewes. J. Anim. Sci. 41, 1400-1406.

Hawk, H.W., Conley, H.H. \& Cooper, B.S. (1978) Number of sperm in the oviducts, uterus, and cervix of the mated ewe as affected by exogenous estradiol. J. Anim. Sci. 46, 1300-1308.

Hulet, C.V., Foote, W.C. \& Blackwell, R.L. (1965) Relationship of semen quality and fertility in the ram to fecundity in the ewe. J. Reprod. Fert. 9, 311-315.

Hunter, R.H.F. (1967) The effects of delayed insemination on fertilization and early cleavage in the pig. $J$. Reprod. Fert. 13, 133-147.

Kelly, R.W. (1982) Reproductive performance of commercial sheep flocks in South Island districts. 1. Flock performance and sources of wastage between joining and tailing. N.Z. J. agric. Res. 25, 175-183.

Kelly, R.W. \& Allison, A.J. (1976) Measurement of ovulation rates by laparoscopy and effects on reproductive performance. Proc. N.Z. Soc. Anim. Prod. 36, 240-246.
Kelly, R.W. \& Johnstone, P.D. (1983) Influence of site of ovulation on the reproductive performance of ewes with I or 2 ovulations. N.Z. J. agric. Res. 26, $433-435$.

Kelly, R.W., Allison, A.J. \& Johnstone, P.D. (1978) A system of identifying factors limiting the reproductive performance of commercial sheep flocks. Proc. N.Z. Soc. Anim. Prod. 38, 80-89.

Killeen, I.D. \& Moore, N.W. (1970) Fertilization and survival of fertilized eggs in the ewe following surgical insemination at various times after the onset of oestrus. Aust. J. biol. Sci. 23, 1279-1287.

Knight, T.W., Oldham, C.M., Smith, J.F. \& Lindsay, D.R. (1975) Studies on ovine fertility in agricultural regions in Western Australia: analysis of reproductive wastage. Aust. J. exp. Agric. Anim. Husb. 15, $183-188$.

Lindsay, D.R., Knight, T.W., Smith, J.F. \& Oldham, C.M. (1975) Studies in ovine infertility in agricultural regions of Western Australia: ovulation rate, fertility and lambing performance. Aust. J. agric. Res. 26, 189-198.

McCullagh, P. \& Nelder, J.A. (1983) Generalized Linear Models. Chapman and Hall, London.

Mattner, P.E. \& Braden, A.W.H. (1967) Studies on flock mating of sheep. 2. Fertilization and prenatal mortality. Aust. J. exp. Agric. Anim. Husb. 7, $110-116$.

Moore, R.W. (1981) Fertilization rate of ewes mated to high and low prolificacy Romney rams. Proc. N.Z. Soc. Anim. Prod. 41, 224-228.

Nancarrow, C.D., Murray, J.D., Scaramuzzi, R.J., Marshall, J.T., Hazelton, I.G., Hoskinson, R.M. \& Boland, M.P. (1985) Fertilization and embryo development in androstenedione-immune sheep. Proc. Aust. Soc. Reprod. Biol. 17, 6, Abstr.

Oldham, C.M. \& Lindsay, D.R. (1984) The minimum period of intake of lupin grain required by ewes to increase their ovulation rate when grazing dry summer pasture. In Reproduction in Sheep, pp. 274-276. Eds D. R. Lindsay \& D. T. Pearce. Australian Academy of Science, Canberra.

Oldham, C.M., Knight, T.W. \& Lindsay, D.R. (1976) A comparison of the effect on reproductive performance in sheep of two methods of estimation of ovulation rate. Aust. J. exp. Agric. Anim. Husb. 16, 24-27.

Pearce, D.T. (1981) Factors affecting sperm transport in the ewe. Ph.D. thesis, University of Sydney.

Quinlivan, T.D. \& Robinson, T.J. (1967) The number of spermatozoa in the fallopian tube of ewes at intervals after artificial insemination following withdrawal of SC-9880-impregnated intravaginal sponges. In The Control of the Ovarian Cycle in the Sheep, pp. 177-194. Ed. T. J. Robinson, Sydney University Press.

Restall, B.J., Brown, G.H., Blockey, M.A. de B., Cahill, L.P. \& Kearins, R. (1976) Assessment of reproductive wastage in sheep. I. Fertilization failure and early embryonic survival. Aust. J. exp. Agric. Anim. Husb. 16, 329-335.

Robinson, T.J., Moore, N.W., Lindsay, D.R., Fletcher, I.C. \& Salamon, S. (1970) Fertility following synchronization of oestrous in the sheep with intravaginal sponges. Effects of Vaginal douche, supplementary 
steroids, time of insemination, and numbers and dilution of spermatozoa. Aust. J. agric. Res. 21, $767-781$.

Salamon, S. (1976) Artificial Insemination in Sheep. Publicity Press Ltd, Chippendale, NSW.
Wilkins, J.F. \& Fowler, D.G. (1984) Ultrasound imaging for litter size diagnosis in breeding flocks. In Reproduction in Sheep, pp. 182-184. Eds D. R. Lindsay \& D. T. Pearce. Australian Academy of Science, Canberra.

Received 29 October, 1987 